\title{
Effects of dietary protein level and rumen-protected pantothenate on nutrient digestibility, nitrogen balance, blood metabolites and growth performance in beef calves
}

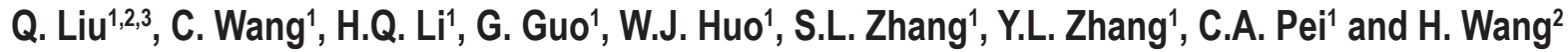 \\ ${ }^{1}$ Shanxi Agricultural University, College of Animal Sciences and Veterinary Medicines, Taigu, 030801, Shanxi Province, P.R. China \\ ${ }^{2}$ Animal Husbandry and Veterinary Bureau of Yuci County, Yuci, 030600, Shanxi Province, P.R. China
}

KEY WORDS: rumen-protected pantothenate, protein, digestibility, nitrogen balance, blood analysis, calves

Received: 18 June 2017

Revised: 23 May 2018

Accepted: 26 July 2018
${ }^{3}$ Corresponding author:

e-mail: liuqiangabc@163.com
ABSTRACT. The aim of the study was to evaluate the effects of dietary different levels of crude protein (CP) and rumen-protected pantothenate (RPP) supplementation on nutrient digestibility, nitrogen balance, blood metabolites and growth performance in beef calves. Sixty Blonde d'Aquitaine $\times$ Simmental bull calves (in average 12 months of age and $354 \pm 2.4 \mathrm{~kg}$ of body weight) were randomly assigned to four groups with a $2 \times 2$ factorial arrangement. Low CP $(113,7 \mathrm{~g} / \mathrm{kg}$ dry matter (DM)) or high CP $(133,9 \mathrm{~g} / \mathrm{kg}$ DM) diets were fed without or with $72 \mathrm{mg}$ RPP per $\mathrm{kg}$ DM. The feeding experiment lasted 100 days (10 days of adaptation and 90 days of target feeding and data collection). After feeding experiment, 4 calves per treatment (still fed the same diet) were randomly selected for collection of faeces and urine from day 111 to 120 . CP $x$ RPP interactions were not observed. DM intake, average daily gain, digestibility of DM, organic matter, $\mathrm{CP}$, neutral detergent fibre and acid detergent fibre, digestible $N(D N)$, retained $N(R N)$, $D N: N$ intake ratio and RN:DN ratio increased, and feed conversion ratio decreased with increasing dietary $\mathrm{CP}$ level or RPP supplementation. Serum total protein and albumin contents increased with increasing dietary CP level or RPP supplementation. Serum urea nitrogen increased with increasing dietary $\mathrm{CP}$ level, but decreased with RPP supplementation. Serum concentrations of 3-hydroxy-3-methylglutarylCoA synthetase, pantothenic acid, acyl carrier protein and acetyl-CoA as well as activities of pantothenate kinase and succinyl-CoA were not affected by dietary CP level, but increased with RPP supplementation. So, nutrient utilization and growth performance were improved with increasing dietary CP level or RPP supplementation in beef calves.

\section{Introduction}

Adequate dietary crude protein (CP) supplementation is necessary to maintain ruminal fermentation and production performance of animals. It was found that increasing dietary protein content enhanced dry matter (DM) intake (Galles et al., 2011; Detmann et al., 2014), ruminal bacteria growth (Chanthakhoun et al., 2012), nutrient digestibility, microbial protein synthesis, N utilization (Chanthakhoun et al., 2012) and growth performance (Detmann et al., 2014). However, the excretion of faecal $\mathrm{N}$ and urinary $\mathrm{N}$ also increased with increasing dietary CP level (Lohakare et al., 2006; Galles et al., 2011), leading to an increased environmental pollution. Therefore, it is necessary to improve $\mathrm{N}$ utilization for high protein diets. 
Pantothenic acid (PA) is involved in the energy release from carbohydrate, fatty acids and protein as well as in the biosynthesis of fatty acids by incorporating into coenzyme $\mathrm{A}(\mathrm{CoA})$ and acyl carrier protein (ACP) (Ball, 2006). It has been reported that PA was required for the growth of some strains of Lactobacillus, Streptococcus and Megasphaera elsdenii (Ford et al., 1958; Wolin et al., 1997) and positively affected protozoa counts in vitro (Völker et al., 2011). The amount of ruminally synthesized PA has been estimated to be 20 to 30 times higher than normal dietary amounts experienced by cattle (National Academies of Sciences, Engineering, and Medicine, 2016). Nevertheless, the requirement of PA has not been established for beef cattle with well-developed rumen. Moreover, degradability of dietary supplemented PA was 0.8 (Zinn et al., 1987), thus, rumen-protected pantothenate (RPP) supplement should be used in farming practice. Our previous studies indicated that ruminal total volatile fatty acids (VFA) concentration, degradability of neutral detergent fibre (NDF) and CP, bacteria abundance, microbial enzyme activity and microbial protein synthesis increased with RPP supplementation in Blonde d'Aquitaine $\times$ Simmental beef steers with $363 \mathrm{~kg}$ of body weight (Li et al., 2017) or with $462 \mathrm{~kg}$ of body weight (Liu et al., 2017). Wang et al. (2018) found that digestibility of DM, organic matter $(\mathrm{OM})$ and $\mathrm{CP}$ increased, and NDF and acid detergent fibre (ADF) tended to increase with RPP supplementation in dairy cows. Moreover, milk and milk component yields increased with RPP supplementation (Bonomi, 2000; Wang et al., 2018).

These data indicated that the supplementation of RPP enhanced dietary $\mathrm{N}$ utilization, as evidenced by the increased microbial protein synthesis and milk protein yield (Bonomi, 2000; Liu et al., 2017). Additionally, PA or pantothenate participate in protein metabolism of the body via CoA and ACP (Ball, 2006). Thus, it was hypothesized that there might be an interaction between dietary CP level and RPP supplementation, and the supplementation of RPP might enhance N utilization of high protein diets. So, the aim of the current study was to evaluate the effects of RPP supplementation and dietary protein level on nutrient digestibility, nitrogen balance, blood metabolites and growth performance in Blonde d'Aquitaine $\times$ Simmental calves, and to find out whether the CP $\times$ RPP interaction exists.

\section{Material and methods}

\section{Animals and experimental design}

The experimental protocol was approved by the Animal Care and Use Committee of Shanxi Agriculture University (Taigu County, Shanxi Province, China). Sixty, 12-month-old Blonde d'Aquitaine $\times$ Simmental bull calves with similar body weight (BW; $354 \pm 2.4 \mathrm{~kg}$ ) were purchased from three beef cattle farms using the same feeding and management practices. The animals were selected from the progeny of multiparous Simmental cows ( $n=300$ per farm) that were synchronized and artificially inseminated by the same Blonde d'Aquitaine sire, and randomly assigned to four experimental groups $(n=15)$ in a $2 \times 2$ factorial design. The factors were: the dietary CP level either with low (LP) or high (HP) $\mathrm{CP}(113.7 \mathrm{~g} \mathrm{CP} / \mathrm{kg}$ and $133.9 \mathrm{~g} \mathrm{CP} / \mathrm{kg} \mathrm{DM}$, respectively), and the level of RPP either with $0 \mathrm{mg} / \mathrm{kg}$ $\mathrm{DM}$ (control) or $72 \mathrm{mg} / \mathrm{kg} \mathrm{DM}$ (RPP+). The experimental diets were formulated to meet the nutritional requirements for crossbred cattle (daily gain of 1.00 and $1.50 \mathrm{~kg} / \mathrm{d}$ for LP and HP groups, respectively) (da Silva et al., 2016).

Supplementary RPP contained $150 \mathrm{~g} / \mathrm{kg}$ of D-calcium pantothenate and was manually mixed with the first third of the morning ration to ensure its complete consumption. The supplement was produced according to the method of Wang et al. (2016) and manufactured by Shanxi Jushuoyuan Biological Technology Co., Ltd (Taiyuan, China). Degradability of RPP in the rumen and in the small intestine was 20 and $60 \%$, respectively, as determined in situ using rumen and duodenal cannulated cattle (Wang et al., 2016). The supplemental dose of pantothenate in the form of RPP was determined according to previous studies (Li et al., 2017; Liu et al., 2017). Calves were fed a total mixed ration (TMR), ensiled maize forage to concentrate ratio was 50:50 (DM basis, Table 1).

The experiment lasted 100 days with 10-day adaptation-period and a 90-day test-period. Calves were housed in individual pens $(3 \times 3.5 \mathrm{~m})$. After the feeding experiment, 4 calves per treatment were randomly selected and housed in metabolism stalls $(1 \times 2 \mathrm{~m}$, slatted floors and rubber mats $)$ in a ventilated room, and harnessed with a faecal collection bag and a urine funnel for total collection of faeces and urine from days 111 to 120 . All calves from days 1 to 120 were fed twice a day at 07:00 and 19:00, clean water was available throughout the experimental period. 
Table 1. Ingredient and chemical composition of low protein (LP) and high protein (HP) diets

\begin{tabular}{lcc}
\hline \multirow{2}{*}{ Indices } & \multicolumn{2}{l}{ Diet } \\
\cline { 2 - 3 } & LP & HP \\
\hline Ingredients, g/kg dry matter & & \\
ensiled maize forage & 500 & 500 \\
maize grain, ground & 266 & 221 \\
wheat bran & 60 & 60 \\
soybean meal & 40 & 75 \\
cottonseed cake & 80 & 100 \\
calcium carbonate & 13 & 13 \\
salt & 5.0 & 5.0 \\
calcium hydrogen phosphate & 30 & 20 \\
sodium bicarbonate & 5.0 & 5.0 \\
mineral and vitamin premix & 1.0 & 1.0 \\
Analysed chemical composition, g/kg diet & \\
organic matter & 945.6 & 942.4 \\
crude protein & 113.7 & 133.9 \\
neutral detergent fibre & 395.6 & 400.5 \\
acid detergent fibre & 256.7 & 252.4 \\
calcium & 5.6 & 5.7 \\
phosphorus & 3.3 & 3.5 \\
\hline
\end{tabular}

${ }^{1} \mathrm{~kg}$ of the premix contained: mg: Co 120, Cu 8400, Fe 45000, Mn 32000, Zn 33000, I 300, Se 320; IU: vit. A 7600000, vit. D 1300000 , vit. E 42000

\section{Performance measurements and samples collection}

The amounts of feed and refusals were individually recorded once a day at days 11-100 (days 1-90 of test-period) and 111-120. Calves were weighed for two consecutive days on day 1 and 2, 30 and 31, 60 and 61, and 90 and 91 of the test-period at the same time relative to feeding. Samples of TMR and refusals were collected once a day and then composited by calf every 10 days for DM determination. Diets and refusals were dried in an oven at $55^{\circ} \mathrm{C}$ for $48 \mathrm{~h}$, then ground to pass a $1-\mathrm{mm}$ sieve with a cutter mill (110, Qingdao Ruixintai instrument Co., Ltd., Qingdao, China) for further chemical analysis. Faecal excretion was recorded from day 111 to 120 and samples (1/15 of wet weight) were collected, then $100 \mathrm{~g} / 1$ tartaric acid solution ( $1 / 4$ of samples) was mixed into the samples. After drying at $55{ }^{\circ} \mathrm{C}$ for $48 \mathrm{~h}$, the faecal samples were ground to pass through a $1-\mathrm{mm}$ screen and pooled by calf for chemical analysis. Urine samples $(1 / 100$ of volume) were collected to a container containing $10 \mathrm{ml}$ dimethylbenzenes and stored at $4{ }^{\circ} \mathrm{C}$. Blood samples were obtained on 2 consecutive days at the end of the feeding period. Samples were collected $2 \mathrm{~h}$ after the morning feeding from the jugular vein and then placed on ice and transported to the laboratory to separate serum by centrifuging at $3000 \mathrm{~g}$ for $10 \mathrm{~min}$ at $4{ }^{\circ} \mathrm{C}$. All serum samples were stored at $-20^{\circ} \mathrm{C}$ until analysis.

\section{Chemical analyses}

The DM content of samples was determined by desiccating at $135{ }^{\circ} \mathrm{C}$ for $3 \mathrm{~h}$ (method 930.15; AOAC International, 1995). Ash content was measured by combustion at $550{ }^{\circ} \mathrm{C}$ for $5 \mathrm{~h}$, and $\mathrm{OM}$ content was calculated as the difference between $\mathrm{DM}$ and ash contents. Content of $\mathrm{N}$ was measured by the Kjeldahl method (method 976.05; AOAC International, 1995). Contents of NDF and ADF were measured according to the procedure of Van Soest et al. (1991) with heat stable $\alpha$-amylase and sodium sulphite used in the NDF procedure, and expressed inclusive of residual ash. Concentrations of pantothenate in the RPP and feed residues were measured by high performance liquid chromatography (Agilent 1260 Infinity HPLC, Agilent Technologies, Santa Clara, CA, USA) according to the method of Romera et al. (1996). Serum concentrations of glucose, total protein, albumin, serum urea nitrogen (SUN) and triglyceride were determined using the corresponding colorimetric assay kits (Nanjing Jian Cheng Institute of Bio-engineering, Nanjing, China). Concentrations of PA, 3-hydroxy3-methylglutaryl-CoA synthetase (HMGCS), ACP and acetyl-CoA as well as activities of pantothenate kinase (PANK) and succinyl-CoA were determined with the Konelab TM auto analyzer (Thermo Fisher Scientific Oy, Vantaa, Finland) by using the corresponding enzyme-linked immunosorbent assay (ELISA) kits (Shanghai Du Ma Biology Science \& Technology Co., Ltd, Shanghai, China).

\section{Calculations and statistical analyses}

Feed conversion ratio (FCR) for each calf was calculated by dividing DMI by ADG during the experiment. Digestible nitrogen (DN, g/d) was estimated by the difference between $\mathrm{N}$ intake and faecal $\mathrm{N}$ excretion. Retained N (RN, g/d) was calculated as the difference between $\mathrm{DN}$ and urinary $\mathrm{N}$ excretion. Data were analysed using the general linear model procedure of SAS Software version 9 (Procedure GLM; SAS Institute Inc., Cary, NC, USA).

Dietary CP level and RPP supplementation were considered as fixed effects. The $P$-values presented in tables are for the main effect of supplied CP (LP vs HP), the main effect of RPP (control vs $\mathrm{RPP}+)$ and their interaction $(\mathrm{CP} \times \mathrm{RPP})$. Effects of the factors were declared significant at $P<0.05$. 


\section{Results}

\section{Dry matter intake, average daily gain and feed conversion ratio}

No CP $\times$ RPP interaction effects on DM intake (DMI), ADG and FCR during test-period at days 1-30, 31-60, 61-90, and overall were observed (Table 2). For each period of target feeding (days 1 to 30,31 to 60 and 61 to 90), DMI and ADG increased $(P<0.05)$, and FCR decreased $(P<0.05)$ with increasing dietary CP level or RPP supplementation. As a result, overall DMI and ADG increased $(P<0.05)$, and FCR decreased $(P<0.05)$ with increasing dietary CP level or RPP supplementation. The initial weight (day 1 of the test-period) of animals was similar among treatments. The BW of animals for days 30,60 and 90 of feeding period was not affected by dietary CP level, but increased $(P<0.05)$ with RPP supplementation.

\section{Nutrient digestibility and nitrogen balance}

Nutrient digestibility and nitrogen balance were not affected by $\mathrm{CP} \times \mathrm{RPP}$ interaction (Tables 3 and 4).
Digestibility of DM, OM, CP, NDF and ADF increased $(P<0.05)$ with increasing dietary CP level or RPP supplementation. Nitrogen intake and urinary $\mathrm{N}$ excretion increased $(P<0.05)$ with increasing dietary CP level, but were not affected by RPP supplementation. Faecal $\mathrm{N}$ and total $\mathrm{N}$ excretions were not affected, but DN, RN, RN:N intake ratio and $\mathrm{RN}$ :DN ratio increased $(P<0.05)$ with increasing dietary CP level or RPP supplementation.

\section{Blood metabolites}

Blood metabolites were not affected by $\mathrm{CP} \times \mathrm{RPP}$ interaction (Table 5). Blood glucose and triglyceride contents were not affected, but total protein and albumin levels increased $(P<0.05)$ with increasing dietary CP level or RPP supplementation. Content of SUN increased $(P=0.042)$ with increasing dietary CP level, but decreased $(P=0.037)$ with RPP supplementation. Concentrations of PA, HMGCS, ACP and acetyl-CoA as well as activities of PANK and succinyl-CoA were not affected by dietary $\mathrm{CP}$ level, but increased $(P<0.05)$ with RPP supplementation.

Table 2. Effects of dietary crude protein (CP) level and rumen-protected pantothenate (RPP) supplementation on dry matter intake (DMI), average daily gain (ADG) and feed conversion rate (FCR) in Blonde d'Aquitaine $\times$ Simmental calves

\begin{tabular}{|c|c|c|c|c|c|c|c|c|}
\hline \multirow{3}{*}{ Indices } & \multicolumn{4}{|l|}{ Diet $^{1}$} & \multirow{3}{*}{ SE } & \multirow{2}{*}{\multicolumn{3}{|c|}{ Effect $^{2}, P$-value }} \\
\hline & \multicolumn{2}{|l|}{$\mathrm{LP}$} & \multicolumn{2}{|l|}{$\mathrm{HP}$} & & & & \\
\hline & control & RPP & control & RPP & & $\overline{\mathrm{CP}}$ & RPP & $\mathrm{CP} \times \mathrm{RPP}$ \\
\hline \multicolumn{9}{|l|}{ DMI, kg/day } \\
\hline days $1-30$ & 8.61 & 9.16 & 8.99 & 9.46 & 0.058 & 0.005 & 0.015 & 0.387 \\
\hline $31-60$ & 9.38 & 10.11 & 9.85 & 10.53 & 0.063 & 0.006 & 0.017 & 0.465 \\
\hline $61-90$ & 10.20 & 11.15 & 10.83 & 11.68 & 0.079 & 0.002 & 0.011 & 0.504 \\
\hline overall & 9.40 & 10.14 & 9.89 & 10.56 & 0.061 & 0.003 & 0.012 & 0.498 \\
\hline \multicolumn{9}{|c|}{ Body weight, kg } \\
\hline day 1 & 354.7 & 352.8 & 355.6 & 352.4 & 0.634 & 0.743 & 0.173 & 0.335 \\
\hline 30 & 386.9 & 389.9 & 389.8 & 392.6 & 0.813 & 0.436 & 0.021 & 0.364 \\
\hline 60 & 421.6 & 430.3 & 427.9 & 436.5 & 0.925 & 0.287 & 0.016 & 0.405 \\
\hline 90 & 458.2 & 475.2 & 471.7 & 485.6 & 0.906 & 0.315 & 0.012 & 0.398 \\
\hline \multicolumn{9}{|l|}{ ADG, kg/day } \\
\hline days $1-30$ & 1.07 & 1.24 & 1.14 & 1.34 & 0.009 & 0.039 & 0.018 & 0.573 \\
\hline $31-60$ & 1.16 & 1.35 & 1.27 & 1.46 & 0.011 & 0.027 & 0.025 & 0.489 \\
\hline $61-90$ & 1.22 & 1.50 & 1.46 & 1.64 & 0.013 & 0.031 & 0.014 & 0.607 \\
\hline overall & 1.15 & 1.36 & 1.29 & 1.48 & 0.011 & 0.047 & 0.005 & 0.686 \\
\hline \multicolumn{9}{|c|}{$\mathrm{FCR}^{3}, \mathrm{~kg} / \mathrm{day}$} \\
\hline days $1-30$ & 8.02 & 7.41 & 7.89 & 7.06 & 0.017 & 0.029 & 0.043 & 0.143 \\
\hline $31-60$ & 8.11 & 7.51 & 7.76 & 7.20 & 0.021 & 0.037 & 0.035 & 0.137 \\
\hline $61-90$ & 8.36 & 7.45 & 7.42 & 7.14 & 0.024 & 0.024 & 0.022 & 0.115 \\
\hline overall & 8.17 & 7.46 & 7.67 & 7.13 & 0.022 & 0.032 & 0.011 & 0.102 \\
\hline
\end{tabular}

1 LP - low protein diet (113.7 g CP/day dry matter (DM)), HP - high protein diet (133.9 g CP/day DM); control - diet without rumen-protected pantothenate addition, RPP - diet with $72 \mathrm{mg}$ rumen-protected pantothenate addition per $\mathrm{kg}$ of dietary DM; ${ }^{2}$ effect: CP - crude protein level effect, RPP - rumen-protected pantothenate addition effect, CP $\times$ RPP - interaction between crude protein level and rumen-protected pantothenate addition; ${ }^{3}$ FCR = DMI (kg/day) / ADG (kg/day); SE - standard error 
Table 3. Effects of dietary crude protein (CP) level and rumen-protected pantothenate (RPP) supplementation on nutrient digestibility in the total tract in Blonde d'Aquitaine $\times$ Simmental calves, $\mathrm{g} / \mathrm{g}$

\begin{tabular}{|c|c|c|c|c|c|c|c|c|}
\hline \multirow{3}{*}{ Digestibility } & \multicolumn{4}{|l|}{ Diet $^{1}$} & \multirow{3}{*}{ SE } & \multirow{2}{*}{\multicolumn{3}{|c|}{ Effect ${ }^{2}, P$-value }} \\
\hline & \multicolumn{2}{|l|}{$\overline{\mathrm{LP}}$} & \multicolumn{2}{|l|}{$\mathrm{HP}$} & & & & \\
\hline & control & RPP & control & RPP & & $\overline{\mathrm{CP}}$ & RPP & $\mathrm{CP} \times \mathrm{RPP}$ \\
\hline Dry matter & 0.579 & 0.603 & 0.596 & 0.624 & 0.005 & 0.003 & 0.002 & 0.585 \\
\hline Organic matter & 0.632 & 0.658 & 0.667 & 0.689 & 0.012 & 0.006 & 0.005 & 0.606 \\
\hline Crude protein & 0.653 & 0.681 & 0.692 & 0.721 & 0.008 & 0.014 & 0.018 & 0.730 \\
\hline Neutral detergent fibre & 0.476 & 0.502 & 0.495 & 0.526 & 0.009 & 0.009 & 0.011 & 0.379 \\
\hline Acid detergent fibre & 0.415 & 0.439 & 0.428 & 0.457 & 0.011 & 0.007 & 0.024 & 0.493 \\
\hline
\end{tabular}

1,2 see Table 2, SE - standard error

Table 4. Effects of dietary crude protein (CP) level and rumen-protected pantothenate (RPP) supplementation on nitrogen (N) balance in Blonde d'Aquitaine $\times$ Simmental calves

\begin{tabular}{|c|c|c|c|c|c|c|c|c|}
\hline \multirow{3}{*}{ Indices } & \multicolumn{4}{|l|}{ Diet $^{1}$} & \multirow{3}{*}{ SE } & \multirow{2}{*}{\multicolumn{3}{|c|}{ Effect $^{2}, P$-value }} \\
\hline & \multicolumn{2}{|l|}{$\mathrm{LP}$} & \multicolumn{2}{|l|}{$\mathrm{HP}$} & & & & \\
\hline & control & RPP & control & RPP & & $\overline{C P}$ & RPP & $\mathrm{CP} \times \mathrm{RPP}$ \\
\hline \multicolumn{9}{|l|}{ g/day } \\
\hline $\mathrm{N}$ intake & 177.2 & 189.4 & 218.3 & 231.3 & 2.732 & 0.026 & 0.187 & 0.156 \\
\hline fecal N & 61.49 & 60.42 & 67.23 & 64.53 & 0.864 & 0.075 & 0.069 & 0.128 \\
\hline urinary $\mathrm{N}$ & 55.67 & 52.13 & 64.35 & 62.17 & 1.746 & 0.042 & 0.135 & 0.246 \\
\hline total $\mathrm{N}$ excreted & 117.2 & 112.6 & 131.6 & 126.7 & 2.413 & 0.065 & 0.094 & 0.317 \\
\hline DN & 115.7 & 129.0 & 151.0 & 166.8 & 2.575 & 0.017 & 0.043 & 0.479 \\
\hline RN & 60.04 & 76.86 & 86.69 & 104.6 & 1.642 & 0.021 & 0.036 & 0.147 \\
\hline \multicolumn{9}{|l|}{$g / g$} \\
\hline $\mathrm{RN}: \mathrm{N}$ intake & 0.339 & 0.406 & 0.397 & 0.452 & 0.011 & 0.038 & 0.041 & 0.549 \\
\hline $\mathrm{RN}: \mathrm{DN}$ & 0.519 & 0.596 & 0.574 & 0.627 & 0.013 & 0.044 & 0.039 & 0.185 \\
\hline
\end{tabular}

1,2 see Table 1, SE - standard error, DN - digestible nitrogen, $\mathrm{RN}$ - retained $\mathrm{N}$

Table 5. Effects of dietary crude protein (CP) level and rumen-protected pantothenate (RPP) supplementation on blood metabolites in Blonde d'Aquitaine $\times$ Simmental calves

\begin{tabular}{|c|c|c|c|c|c|c|c|c|}
\hline \multirow{3}{*}{ Indices } & \multicolumn{4}{|l|}{ Diet $^{1}$} & \multirow{3}{*}{ SE } & \multirow{2}{*}{\multicolumn{3}{|c|}{ Effect ${ }^{2}, P$-value }} \\
\hline & \multicolumn{2}{|l|}{$\mathrm{LP}$} & \multicolumn{2}{|l|}{$\mathrm{HP}$} & & & & \\
\hline & control & RPP & control & RPP & & $\overline{\mathrm{CP}}$ & RPP & $\mathrm{CP} \times \mathrm{RPP}$ \\
\hline Glucose, $\mathrm{mmol} / \mathrm{l}$ & 4.28 & 4.59 & 4.91 & 5.27 & 0.061 & 0.073 & 0.089 & 0.214 \\
\hline Total protein, g/l & 63.58 & 66.76 & 73.42 & 81.54 & 0.573 & 0.025 & 0.043 & 0.147 \\
\hline Albumin, $g / l$ & 33.23 & 35.87 & 39.51 & 46.48 & 0.475 & 0.036 & 0.041 & 0.145 \\
\hline SUN, mmol/l & 4.42 & 3.69 & 5.31 & 4.87 & 0.187 & 0.042 & 0.037 & 0.149 \\
\hline Triglyceride, mmol// & 0.32 & 0.33 & 0.35 & 0.37 & 0.012 & 0.315 & 0.432 & 0.643 \\
\hline HMGCS, pg/ml & 4.26 & 4.81 & 4.39 & 4.96 & 0.073 & 0.357 & 0.039 & 0.684 \\
\hline Pantothenic acid, pmol/ml & 33.28 & 35.57 & 33.46 & 36.35 & 0.652 & 0.736 & 0.046 & 0.589 \\
\hline PANK, U/I & 37.41 & 41.37 & 38.53 & 42.72 & 0.545 & 0.538 & 0.037 & 0.495 \\
\hline Succinyl CoA, U/l & 3.22 & 3.69 & 3.05 & 3.42 & 0.132 & 0.642 & 0.045 & 0.569 \\
\hline $\mathrm{ACP}, \mathrm{ng} / \mathrm{ml}$ & 60.21 & 65.98 & 59.64 & 64.57 & 0.972 & 0.714 & 0.024 & 0.675 \\
\hline Acetyl CoA, ng/ml & 7.38 & 8.15 & 6.79 & 7.61 & 0.185 & 0.356 & 0.038 & 0.482 \\
\hline
\end{tabular}

SUN - serum urea nitrogen, HMGCS - 3-hydroxy-3-methylglutaryl-coenzyme A synthetase, PANK - pantothenate kinase, ACP - acyl carrier protein; ${ }^{1,2}$ see Table $1, \mathrm{SE}$ - standard error

\section{Discussion}

The interaction between dietary $\mathrm{CP}$ level and RPP supplementation was not observed in the current study for any tested parameter. The dose of PA supplemented was about $10.8 \mathrm{mg} / \mathrm{kg} \mathrm{DM}$ or
$110 \mathrm{mg} / \mathrm{d}(72 \mathrm{mg}$ RPP per kg DM, $150 \mathrm{~g}$ PA per $\mathrm{kg}$ RPP, DMI $10.14-10.56 \mathrm{~kg}$ ) in the current study, whereas in the study of Bonomi (2000) the dose of PA supplemented as RPP during the first 5 months of lactation was 50, 100 and $200 \mathrm{mg} / \mathrm{d}$. Different doses of PA were also used by Sacadura et al. (2008), 
who supplemented $193 \mathrm{mg} / \mathrm{d}$ as a rumen-protected $\mathrm{B}$ vitamin blend during the mid-lactation, and Majee et al. (2003), who added 475 or $950 \mathrm{~m} / \mathrm{d}$ as an unprotected B vitamin blend into diet of cows in early lactation. The lower PA dose than in that used in other studies would have been possibly inadequate to cause the interaction between RPP and dietary CP.

\section{Dry matter intake, average daily gain and feed conversion ratio}

The increase in DMI supported the increased ADG with increasing dietary CP level or RPP supplementation. In other studies a positive effect of increasing dietary CP level on DMI was also found (Chen et al., 2010; Detmann et al., 2014). However, da Silva et al. (2016) observed that nutrient intake was not affected by increasing dietary CP level from 110 to $130 \mathrm{~g} / \mathrm{kg}$ DM. A mixture of soybean meal and urea was used as $\mathrm{N}$ source in the study of da Silva et al. (2016), thus, the divergent results may be associated with the different dietary protein composition. Similarly, Wang et al. (2018) found that DMI tended to increase in dairy cows with RPP supplementation. The increased ADG was associated with the increased DM intake, nutrient digestibility and $\mathrm{N}$ utilization, indicating that the growth performance and nutrient utilization improved with increasing dietary CP level or RPP supplementation. Similarly, Detmann et al. (2014) reported that a positive weight gain response to an increased dietary $\mathrm{CP}$ level was observed when dietary $\mathrm{N}$ was deficient in cattle. However, da Silva et al. (2016) reported that ADG of finishing beef cattle (Nellore bulls, initial BW of $374 \pm 16.5 \mathrm{~kg}$ ) was unaltered with increasing dietary CP content from 110 to $130 \mathrm{~g}$ per $\mathrm{kg} \mathrm{DM}$ and suggested that $110 \mathrm{~g} \mathrm{CP}$ was sufficient for the growth of Nellore bulls. Therefore, the different dietary $\mathrm{N}$ levels might have been responsible for such divergent effects of dietary $\mathrm{CP}$ level on ADG of different crossbred cattle. In our previous study it was found that ADG of growing Blonde d'Aquitaine $\times$ Simmental steers increased with RPP supplementation ( $\mathrm{Li}$ et al., 2017). Other studies also reported that milk and milk component yields increased with RPP supplementation at the doses of 50,100 and $200 \mathrm{mg} / \mathrm{d}$ during the first 5 months of lactation (Bonomi, 2000) and at the dose of 90,120 and $150 \mathrm{mg} / \mathrm{d}$ during the midlactation (Wang et al., 2018), or a rumen-protected B vitamin blend (including $193 \mathrm{mg} / \mathrm{d}$ of PA) during the mid-lactation (Sacadura et al., 2008). However, Majee et al. (2003) found that milk yield was not affected by an unprotected B vitamin blend (includ- ing 475 or $950 \mathrm{mg} / \mathrm{d}$ of PA) in early lactation cows. According to Zinn et al. (1987), degradability of dietary supplemented PA was 0.8 . The positive effects of RPP supplementation on production performance could have been associated with a lower ruminal degradability of RPP compared to PA (Bonomi, 2000; Ragaller et al., 2011). Thus, different responses of productive performance to PA supplementation might be associated with stage of lactation, and the dose and mode (rumen-protected vs unprotected) of PA administration.

\section{Nutrient digestibility and nitrogen balance}

The observed increase in the digestibility of DM, OM, CP, NDF and ADF may have resulted from stimulated ruminal microbial growth and enzyme activity with increasing dietary $\mathrm{CP}$ level or RPP supplementation. Increased concentrations of amino acids, peptides, ammonia $\mathrm{N}$ and branchedchain VFA in the rumen with increasing dietary CP level have been observed to stimulate ruminal bacteria growth and to promote microbial enzyme secretion (Atasoglu et al., 2001; Liu et al., 2014). Also, Lohakare et al. (2006) reported that nutrient digestibility increased with increasing dietary $\mathrm{CP}$ level. However, da Silva et al. (2016) found no effect of dietary CP level on nutrient digestibility, which may have resulted from another dietary protein composition (mixture of soybean meal and urea) in that study. It has been reported that PA was required for the growth of some strains of Lactobacillus, Streptococcus and Megasphaera elsdenii (Ford et al., 1958; Wolin et al., 1997) and positively affected protozoa counts in vitro (Völker et al., 2011). The supplementation of PA improved intestinal function of rats (Seronde, 1963). Moreover, previous studies found that ruminal bacteria abundance, enzyme activity and degradability of NDF and CP increased with RPP supplementation in steers $(\mathrm{Li}$ et al., 2017; Liu et al., 2017). Wang et al. (2018) observed that digestibility of DM, OM and CP increased, and NDF and ADF tended to increase with RPP supplementation in dairy cows. However, other studies reported that ruminal apparent digestibility of OM, NDF and ADF were unaltered by PA or mixture of B vitamins containing PA supplementation (Majee et al., 2003; Ragaller et al., 2011).

The increase in $\mathrm{DN}, \mathrm{RN}$ and $\mathrm{RN}$ :DN ratio indicated that the utilization of dietary $\mathrm{N}$ was enhanced, and supported the increased ADG with increasing dietary CP level or RPP supplementation. The higher utilization of dietary $\mathrm{N}$ mainly resulted from an enhanced $\mathrm{CP}$ digestibility and microbial protein 
synthesis with increasing dietary CP level or RPP supplementation. The increased $\mathrm{CP}$ digestibility, microbial protein synthesis and $\mathrm{N}$ retention with increasing dietary CP level were observed in other studies (Galles et al., 2011; Chanthakhoun et al., 2012). In the current study, $N$ intake increased by $22.6 \%$ with increasing dietary $\mathrm{CP}$ level, while total $\mathrm{N}$ excreted was only elevated by $12.4 \%$, so that the retained $\mathrm{N}$ increased by $39.7 \%$. It is suggested that the more efficient utilization of dietary $\mathrm{N}$ with increasing dietary $\mathrm{CP}$ level was not only related to the increased $\mathrm{N}$ intake but also to a higher $\mathrm{CP}$ digestibility and microbial protein synthesis. Similarly, in previous studies an increased microbial protein synthesis with RPP supplementation in steers was observed (Li et al., 2017; Liu et al., 2017). Also, in other studies the increased milk protein yield with RPP supplementation (Bonomi, 2000; Wang et al., 2018) confirmed that the utilization of dietary $\mathrm{N}$ was improved by RPP supplementation.

\section{Blood metabolites}

The unaltered serum glucose content indicated that the gluconeogenesis might have been unaffected with increasing dietary CP level or RPP supplementation. Lohakare et al. (2006) also found an unaltered serum glucose content with increasing dietary $\mathrm{CP}$ level. Ragaller et al. (2011) reported that serum glucose content was unaltered with PA supplementation to the diet with 34:66 concentrate:forage ratio but it decreased when dietary concentrate and forage were fed at ratio 66:34. However, in other studies a higher blood glucose concentration in dairy cows with PA or RPP supplementation was observed (Bonomi, 2000; Wang et al., 2018). The deviating results might have been related to different dietary concentrate:forage ratios and animals used in these studies. The higher serum urea nitrogen (SUN) concentration might be associated with an increased ruminal $\mathrm{CP}$ degradability with increasing dietary CP level, as observed in the study of Liu et al. (2017). Blood total protein and albumin contents can be regarded as parameters for intermediary protein availability, as albumin plays an important role in amino acids transport (Lohakare et al., 2006; Oh et al., 2008). The higher serum concentrations of total protein and albumin with increasing dietary $\mathrm{CP}$ level or RPP supplementation may have resulted from an increased intermediary $\mathrm{N}$ availability. $\mathrm{Oh}$ et al. (2008) also reported that blood concentrations of albumin and SUN increased with increasing dietary CP level. The decrease in SUN concentration observed with RPP supplementation indicates that $\mathrm{N}$ utilization was raised. Wang et al. (2018) also found that serum total protein concentration increased and SUN decreased with RPP supplementation in dairy cows.

The ketogenesis is a secondary metabolic pathway to provide energy for ruminants, however a subclinical metabolic disorder may occur when the production of ketone bodies is above certain levels (Melendez et al., 2016). The HMGCS is a ratelimiting enzyme for ketogenesis in ruminants (Connor et al., 2010; Liu et al., 2016). The increase in serum HMGCS concentration indicated that ketone bodies synthesis might be promoted with increasing RPP supplementation. However, Wang et al. (2018) found that serum concentration of HMGCS tended to increase and $\beta$-hydroxybutyrate (BHBA) was unaltered with RPP supplementation in dairy cows. Similarly, Ragaller et al. (2011) found that serum BHBA were not affected with PA supplementation in dairy cows. The increase in serum PA concentration was consistent with the findings of other studies (Bonomi, 2000; Wang et al., 2018), and indicated that the absorption of PA increased with RPP supplementation. However, Ragaller et al. (2011) reported that blood content of PA was unaltered with PA supplementation. The deviating results might have been due to the mode of PA supplementation (rumen-protected or unprotected). The PANK is a rate-limiting enzyme in catalysing the synthesis of CoA and ACP by PA (Jackowski and Rock, 1981). Pantothenic acid affects energy release from carbohydrate, fatty acids and protein as well as fatty acids biosynthesis due to the fact that it is involved in incorporating to CoA and ACP (Ball, 2006). Therefore, the increase in serum PANK activity may have led to increased activity of succinyl-CoA and concentrations of acetyl-CoA and ACP. Increased ADG and decreased FCR after addition of RPP may indicate that energy metabolism is promoted by such supplementation.

\section{Conclusions}

The increasing dietary crude protein (CP) level or rumen-protected pantothenate (RPP) supplementation improved the growth performance and nutrient utilization in calves; however no CP $\times$ RPP interaction was observed during the experiment.

\section{Acknowledgements}

This work was supported by a grant from Agriculture Research and Development projects of Jinzhong Science and Technology Department (Y172007-1), Graduate Student Education Innovation project of Shanxi Province (2016SY023) and Natural Science 
projects of Shanxi Province (201601D011068). The authors thank the staff of Shanxi Agriculture University beef unit for care of the animals.

\section{References}

AOAC International, 1995. Official Methods of Analysis of AOAC International. $16^{\text {th }}$ Edition. Arlington, VA (USA)

Atasoglu C., Newbold C.J., Wallace R.J., 2001. Incorporation of [ $\left.{ }^{15} \mathrm{~N}\right]$ ammonia by the cellulolytic ruminal bacteria Fibrobacter succinogenes BL2, Ruminococcus albus SY3, and Ruminococcus flavefaciens 17. Appl. Environ. Microbiol. 67, 2819-2822, https://doi.org/10.1128/AEM.67.6.2819-2822.2001

Ball G.F.M., 2006. Pantothenic acid. In: G.F.M. Ball (Editor). Vitamins in Foods: Analysis, Bioavailability and Stability. CRC Press. Boca Raton, FL (USA), pp. 211-219

Bonomi A., 2000. Dairy cattle ration integration with rumen-protected pantothenic acid: effects on milk production and reproductive efficiency. Riv. Sci. dell'Aliment. 29, 321-338

Chanthakhoun V., Wanapat M., Berg J., 2012. Level of crude protein in concentrate supplements influenced rumen characteristics, microbial protein synthesis and digestibility in swamp buffaloes (Bubalus bubalis). Livest. Sci. 144, 197-204, https://doi. org/10.1016/j.livsci.2011.11.011

Chen S., Paengkoum P., Xia X., Na-Lumpang P., 2010. Effects of dietary protein on ruminal fermentation, nitrogen utilization and crude protein maintenance in growing Thai-indigenous beef cattle fed rice straw as roughage. J. Anim. Vet. Adv. 9, 23962400, https://doi.org/10.3923/javaa.2010.2396.2400

Connor E.E., Li R.W., Baldwin R.L., Li C., 2010. Gene expression in the digestive tissues of ruminants and their relationships with feeding and digestive processes. Animal 4, 993-1007, https:// doi.org/10.1017/S1751731109991285

da Silva L.D., Pereira O.G., da Silva T.C., Valadares Filho S.C., Ribeiro K.G., 2016. Effects of silage crop and dietary crude protein levels on digestibility, ruminal fermentation, nitrogen use efficiency, and performance of finishing beef cattle. Anim. Feed Sci. Technol. 220, 22-33, https://doi.org/10.1016/j.anifeedsci.2016.07.008

Detmann E., Valente E.E.L., Batista E.D., Huhtanen P., 2014. An evaluation of the performance and efficiency of nitrogen utilization in cattle fed tropical grass pastures with supplementation. Livest. Sci. 162, 141-153, https://doi.org/10.1016/j.livsci.2014.01.029

Ford J.E., Perry K.D., Briggs C.A., 1958. Nutrition of lactic acid bacteria isolated from the rumen. J. Gen. Microbiol. 18, 273-284, https://doi.org/10.1099/00221287-18-1-273

Galles K., Ham J., Westover E., Stratton J., Wagner J., Engle T., Bryant T.C., 2011. Influence of reduced nitrogen diets on ammonia emissions from cattle feedlot pens. Atmosphere 2, 655-670, https://doi.org/10.3390/atmos2040655

Jackowski S., Rock C.O., 1981. Regulation of coenzyme A biosynthesis. J. Bacteriol. 148, 926-932

Li H.Q., Liu Q., Wang C., Guo G., Huo W.J., Zhang S.L., Zhang Y.L., Pei C.X., Yang W.Z., Wang H., 2017. Effects of rumenprotected pantothenate on ruminal fermentation, microbial enzyme activity, cellulolytic bacteria and urinary excretion of purine derivatives in growing beef steers. Livest. Sci 202, 159-165, https://doi.org/10.1016/j.livsci.2017.06.004

Liu Q., Wang C., Li H.Q., Guo G., Huo W.J., Pei C.X., Zhang S.L., Wang H., 2017. Effects of dietary protein levels and rumenprotected pantothenate on ruminal fermentation, microbial enzyme activity and bacteria population in Blonde d'Aquitaine $\times$ Simmental beef steers. Anim. Feed Sci. Technol. 232, 31-39, https://doi.org/10.1016/j.anifeedsci.2017.07.014
Liu Q., Wang C., Pei C.X. et al., 2014. Effects of isovalerate supplementation on microbial status and rumen enzyme profile in steers fed on corn stover based diet. Livest. Sci. 161, 60-68, https://doi.org/10.1016/j.livsci.2013.12.034

Liu Q., Wang C., Zhang Y.L., Pei C.X., Zhang S.L., Li H.Q., Guo G., Huo Y.J., Yang W.Z., Wang H., 2016. Effects of 2-methylbutyrate supplementation on growth performance and ruminal development in pre- and post-weaned dairy calves. Anim. Feed Sci. Technol. 216, 129-137, https://doi.org/10.1016/j. anifeedsci.2016.03.028

Lohakare J.D., Pattanaik A.K., Khan S.A., 2006. Effect of dietary protein levels on the performance, nutrient balances, metabolic profile and thyroid hormones of crossbred calves. Asian-Australas. J. Anim. Sci. 19, 1588-1596, https://doi.org/10.5713/ ajas.2006.1588

Majee D.N., Schwab E.C., Bertics S.J., Seymour W.M., Shaver R.D., 2003. Lactation performance by dairy cows fed supplemental biotin and a B-vitamin blend. J. Dairy Sci. 86, 2106-2112, https://doi.org/10.3168/jds.S0022-0302(03)73800-4

Melendez P., Pinedo P., Bastias J., Marin M.P., Rios C., Bustamante C., Adaro N., Duchens M., 2016. The association between serum $\beta$-hydroxybutyrate and milk fatty acid profile with special emphasis on conjugated linoleic acid in postpartum Holstein cows. BMC Vet. Res. 12, 50, https://doi.org/10.1186/s12917-016-0679-7

National Academies of Sciences, Engineering, and Medicine, 2016. Nutrient Requirements of Beef Cattle. $8^{\text {th }}$ Revised Edition. National Academies Press. Washington, DC (USA), https://doi. org/10.17226/19014

Oh Y.-K., Kim J.-H., Kim K.-H., Choi C.-W., Kang S.-W., Nam I.-S., Kim D.-H., Song M.-K., Kim C.-W., Park K.-K., 2008. Effects of level and degradability of dietary protein on ruminal fermentation and concentrations of soluble non-ammonia nitrogen in ruminal and omasal digesta of Hanwoo steers. AsianAustralas. J. Anim. Sci. 21, 392-403, https://doi.org/10.5713/ ajas.2008.70342

Ragaller V., Lebzien P., Bigalke W., Südekum K.H., Hüther L., Flachowsky G., 2011. Effects of a pantothenic acid supplementation to different rations on ruminal fermentation, nutrient flow at the duodenum, and on blood and milk variables of dairy cows. J. Anim. Physiol. Anim. Nutr. 95, 730-743, https://doi.org/10.1111/j.1439-0396.2010.01103.x

Romera J.M., Ramirez M., Gil A., 1996. Determination of pantothenic acid in infant milk formulas by high performance liquid chromatography. J. Dairy Sci. 79, 523-526, https://doi. org/10.3168/jds.S0022-0302(96)76394-4

Sacadura F.C., Robinson P.H., Evans E., Lordelo M., 2008. Effects of a ruminally protected B-vitamin supplement on milk yield and composition of lactating dairy cows. Anim. Feed Sci. Technol. 144, 111-124, https://doi.org/10.1016/j.anifeedsci.2007.10.005

Seronde J. Jr., 1963. The pathogenesis of duodenal ulcer disease in the pantothenate-deficient rat. Yale J. Biol. Med. 36, 141-156

Van Soest P.J., Robertson J.B., Lewis B.A., 1991. Methods for dietary fiber, neutral detergent fiber, and non-starch polysaccharides in relation to animal nutrition. J. Dairy Sci. 74, 3583-3597, https://doi.org/10.3168/jds.S0022-0302(91)78551-2

Völker D., Hüther L., Daş G., Abel H., 2011. Pantothenic acid supplementation to support rumen microbes? Arch. Anim. Nutr. 65, 163-173, https://doi.org/10.1080/1745039X.2011.552272

Wang C., Liu Q., Guo G., Huo W.J., Ma L., Zhanga Y.L., Pei C.X., Zhang S.L., Wang H., 2016. Effects of rumen-protected folic acid on ruminal fermentation, microbial enzyme activity, cellulolytic bacteria and urinary excretion of purine derivatives in growing beef steers. Anim. Feed Sci. Technol. 221, 185-194, https://doi.org/10.1016/j.anifeedsci.2016.09.006 
Wang C., Liu Q., Li H.Q., Wu X.X., Guo G., Huo W.J., Pei C.X., Zhang Y.L., Zhang S.L., 2018. Effects of rumen-protected pantothenate supplementation on lactation performance, ruminal fermentation, nutrient digestion and blood metabolites in dairy cows. J. Sci. Food Agric. 98, 2098-2104, https://doi. org/10.1002/jsfa.8691

Wolin M.J., Miller T.L., StewartC.S., 1997. Microbe-microbe interactions. In: P.N. Hobson, C.S. Stewart (Editors). The Rumen Microbial Ecosystem. Blackie Academic \& Professional (Chapman \& Hall). London (UK), pp. 467-491
Zinn R.A., Owens F.N., Stuart R.L., Dunbar J.R., Norman B.B., 1987. B-vitamin supplementation of diets for feedlot calves. J. Anim. Sci. 65, 267-277, https://doi.org/10.2527/jas1987.651267x 